\title{
Verdienstelike gids tot die Boeddhisme en meditasie opnuut in Afrikaans uitgegee
}

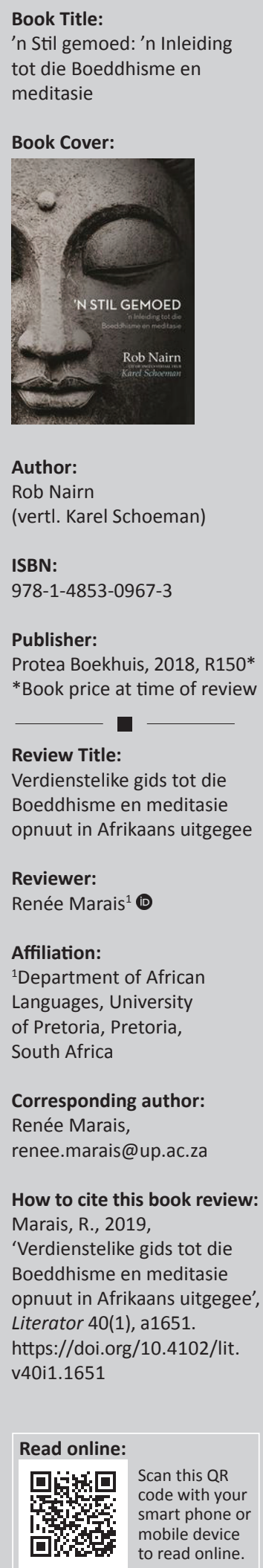

Deur die samewerking van twee meesters is ' $n$ Stil gemoed ' $n$ uitsonderlike publikasie. Rob Nairn se Tranquil mind: An introduction to Buddhism and meditation (Nairn 1993) bied 'n helder en toeganklike inleiding tot die Boeddhisme en meditasie; en Karel Schoeman se Afrikaanse vertaling daarvan (1997) is 'n genot om te lees. Protea Boekhuis se besonder mooi heruitgawe (2018) vervul kennelik 'n lesersbehoefte in Afrikaans én bied hulde aan Schoeman, wat een jaar vóór die publikasie van die heruitgawe oorlede is.

Nairn bedank in 1980 uit sy hoogleraarspos in sielkunde aan die Universiteit van Kaapstad en wy hom aan die Boeddhisme toe. Hy deurloop ' $n$ vier jaar lange afsonderingstydperk by die Samye Ling Tibettaanse Sentrum in Skotland en verwerf mettertyd internasionale aansien as akademikus in die Boeddhisme en meditasie (Nairn 2018:72). Tranquil mind slaag uitmuntend in sy tweeledige doel: om die wesenlike beginsels van die Boeddhisme te verduidelik, en om die leser in die kuns van meditasie in te lei.

In sy kort artikel oor hoe hy Tranquil mind in Afrikaans vertaal het, vra Schoeman (1998:10): 'Het iemand eerder in Afrikaans oor die Boeddhisme probeer skryf of praat? Nie sover ek weet nie.' Natuurlik dink letterkundelesers dadelik aan Die ysterkoei moet sweet (Breytenbach 1964), die debuutdigbundel waarmee Breyten Breytenbach die Zen-Boeddhisme aan Afrikaanse lesers bekendgestel het. Maar Schoeman het deels gelyk: in die Afrikaanse kulturele omgewing van die sestigerjare is selfs die Rooms-Katolisisme as 'n bedreiging beskou, wat nog te sê van 'n filosofie soos die Boeddhisme; en selfs vandag is daar steeds min Afrikaanse literatuur oor die Boeddhisme. ' $n$ Stil gemoed vervul hierdie funksie op uitnemende wyse.

Nairn begin met ' $n$ uiteensetting van wat die Boeddhisme is en wat die Boeddha se leer behels. Die Boeddhisme is 'n aantal metodes om só met die verstand en gemoed om te gaan dat die beoefenaar 'n verligte gees sal ontwikkel, en gevolglik innerlike vrede, erbarming en wysheid sal ervaar (Nairn 2018:11). Ná 'n bespreking van die kenmerke van verdraagsaamheid, erbarming en wysheid, onpartydigheid en toevlug, bespreek Nairn die drie prominentste skole van die Boeddhisme, te wete Theravada (die Leer van die Ouderlinge), Mahayana (die Meerdere Draer) en Vajrayana (die Diamantdraer of Tantra).

Die grondbeginsels van die leer wat die historiese Boeddha, Sakjamoeni, 45 jaar lank in Midde-NoordIndië onderrig het (2500 jaar gelede), behels die Vier Edele Waarhede, die Edele Agtvoudige Weg, dat daar geen self is nie, interafhanklike oorsprong, die Vyf Aggregate, karma en reïnkarnasie, erbarming en die Bodhisattva-ideaal (Nairn 2018:41). Ná 'n bespreking hiervan, fokus Nairn op meditasie - die belangrikste aspek van die Boeddhisme - en bied drie praktiese oefeninge in twee maniere van mediteer: die tradisionele, waar ' $n$ toestand van suiwere aandag bereik word deur op jou asemhaling te fokus, en die alternatiewe manier, waar daar op klank gefokus word.

Erika van Greunen, die uitgewer van Tranquil mind en die persoon wat Schoeman gevra het om die boek in Afrikaans te vertaal, begin haar voorwoord met 'niks is toeval nie', 'n uitspraak wat herhaaldelik in Schoeman se outobiografie voorkom. Schoeman het Tranquil mind toe alreeds met waardering gelees en die Afrikaanse vertaling as 'n uitdaging aanvaar. As Rooms-Katoliek wat 'n jare lange novisiaat deurloop het, was hy vertroud met baie van die beginsels van die Boeddhisme, soos meditasie. Schoeman kon ook (naas ander bronne) gebruik maak van die bestaande Afrikaanse woordeskat van die Rooms-Katolieke Kerk, soos dit in verskeie publikasies en die Kerkwoordeboek (Beraadsliggaam Suid-Afrikaanse Katolieke Biskoppe: Taalkomitee [BSAKBT] 1970) opgeteken is (Schoeman 1998:10-11).

Schoeman bespreek vier begrippe wat sorgvuldige nadenke geverg het om 'n geskikte Afrikaanse vertaalekwivalent te vind. Die eerste is retreat, waarvoor Nederlanders die Franse retraite

Copyright: @ 2019. The Authors. Licensee: AOSIS. This work is licensed under the Creative Commons Attribution License. 
as leenwoord gebruik. Hy het tereg geoordeel dat die Kerkwoordeboek (BSAKBT 1970) se verafrikaanste 'retrêt' nie inslag sou vind nie, en het dus die frase 'tye van afsondering' gebruik (Schoeman 1998:11).

Schoeman het mind (in die titel) met 'gemoed' vertaal, ondanks die enigsins negatiewe gevoelswaarde van uitdrukkings waarin 'gemoed' voorkom. Op kritiek dat dit 'n 'te Westerse vertaling van die Tibetaanse eweknie' sou wees (Schoeman 1998:11), antwoord Schoeman dat hy uit Engels vertaal het, en dat Nairn in sy Engelse bronteks telkens mind gebruik het vir 'n begrip waarvoor daar (volgens Nairn) veertien Tibettaanse woorde bestaan. Naas 'gemoed', gebruik Schoeman ook 'gees' en 'verstand'.

Mindful het onlangs sy weg na Afrikaans gevind as oorlewingstrategie in ons gejaagde samelewing. Schoeman vertaal dit gepas met 'indagtig', wat sowel 'inkeer' as 'dink' oproep. Compassion word in Afrikaans 'erbarming', wat Schoeman (1998:13) positief met Erbarme dich uit Bach se Matteuspassie assosieer.

'Op sy manier is vertaal uiteindelik amper net so subjektief en persoonlik soos skryf', verklaar Schoeman (1998:13). Nairn se 'verbasend helder' skryfstyl (Schoeman, 1998:10) en Schoeman se keurige, idiomatiese vertaling maak 'n Stil gemoed 'n aanwins vir enige leser wat in die Boeddhisme, meditasie, indagtigheid en die werk van Karel Schoeman belangstel.

\section{Literatuurverwysings}

Beraadsliggaam Suid-Afrikaanse Katolieke Biskoppe: Taalkomitee, 1970 Kerkwoordeboek, Katolieke Afrikanersentrum, Pretoria.

Breytenbach, B., 1964, Die ysterkoei moet sweet, APB Publishers and Booksellers, Johannesburg.

Nairn, R., 1993, Tranquil mind: An introduction to Buddhism and meditation, Carrefour/Dragon Publications, Cape Town.

Nairn, R., 1997, 'n Stil gemoed: 'n Inleiding tot die Boeddhisme en meditasie, vertl. K. Schoeman, Protea Boekhuis, Pretoria.

Schoeman, K., 1998, "n Stil gemoed: Gedagtes oor 'n vertaling', Fragmente: Tydskrif vir Filosofie en Kultuurkritiek 2, 10-13. 